Dr Dediu himself was involved in these changes, being employed at the Mathematics Institute at the time of its destruction. He was then transferred to the Physics Institute, but was dismissed before it was re-modelled.

Vera Rich

\section{Change into genes}

Britain's House of Commons Select Committee on Science and Technology is to set up a subcommittee on genetic engineering under the chairmanship of Mr Arthur Palmer, Labour MP for Bristol North East. The members of the committec will be announced shortly, and it is expected that the subcommittee will begin public hearings--to which Ministers are likely to be invited to give evidence-early in the new year.

\section{Conserving energy}

The European Commission in Brussels is considering plans to set up a group within the energy directorate concerned directly with the problems of energy conservation.

The suggestion for such an initiative was made by various environmentalist groups during the public hearings on nuclear energy held in Brussels last week, the first of a series of such hearings on issues related to energy policy.

At the end of the three-day hearings, the chairman Dr Guido Brunner, who is commissioner for energy, announced that the proposal would be seriously considered by the commission, and that it was likely to be put into effect.

The hearing, which concentrated particularly on future energy requirements, saw a number of confrontations between the pro- and the anti-nuclear lobbies, with many well-worn positions being rehearsed by either side.

Putting the case for nuclear power, for example, Dr Rudolf Guck of Badenwerk AG suggested that the declining supply of fossil fuels, leading to a steady climb in prices, would make nuclear energy an increasinglyattractive economic proposition.

According to Dr John Chessire of Sussex University, however, current forecasts of future electricity demand were too high. In addition, whatever the price of uranium, fast breeder reactors would, he claimed, be uneconomic compared with thermal reactors.

Criticism of the European Commission's own energy policy as being "obsolescent" and ignoring "the real needs of society" came from Dr Peter Chapman, director of the Energy Research Group at Britain's Open University.

In a presentation that appeared to make a particular impact on Dr

\title{
Prophet of nuclear doom
}

Mr Tony Benn, UK Secretary of State for Energy, appeared to enjoy last Friday's debate in the House of Commons on nuclear energy.

The debate was brought by Pontypool MP Mr Leo Abse, whose constituents, he said, live within 50 miles of "one of the largest concentrations of nuclear reactors in the world ... eight reactors in operation ... and two more planned".

Abse, who had been briefed by Tom Burke of Friends of the Earth, was demanding a government response to the Flowers report, which indicated the dangers of a headlong dash to dependence on nuclear power. Not mincing words, Abse raised the question "is a plutonium based economy compatible with democracy?" and addressed it with some eloquence.

Abse is not exactly pro-nuclear. $\mathrm{He}$

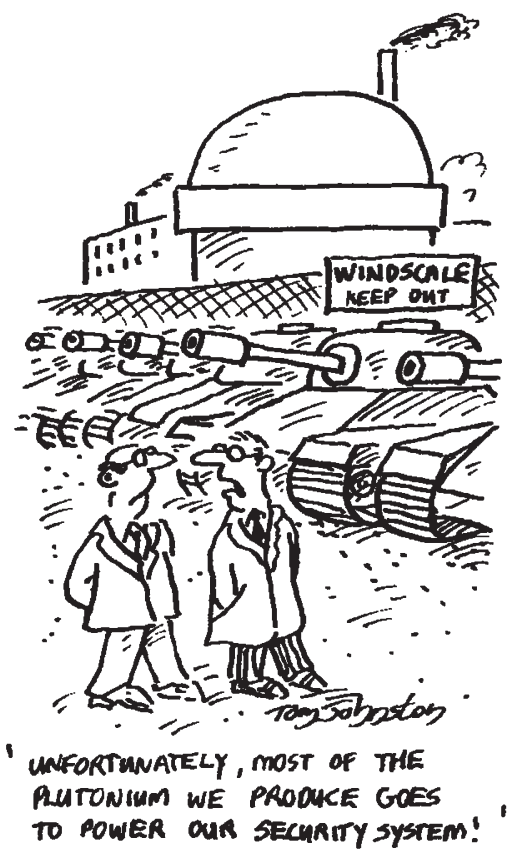

ended "If we, avaricious for the apparently easy wealth that nuclear energy could bring, enter into a Faustian pact with a meretricious atomic destiny, we may have doomed our children or grandchildren to the loss of their liberties, if not their lives".

But that style is very much $\mathrm{Mr}$ Abse's. In more sober moments he took a view broadly against plutonium,

Brunner and other members of the commission present, Dr Chapman claimed that the commission's policy was at least four years behind that of the UK, and that the supply and demand forecasts which it had been putting forward were inappropriate, and of a "very low standard".

"There seems to have been no but not against nuclear energy as such. His points were cogent-as indeed are many of those raised by the Friends of the Earth. Tellingly, Benn was delighted with Abse's speech, which he thought "in a classic prophetic mould". Abse's, said Benn, was a "philosophical, penetrating, and perceptive speech, and I hope that it will be widely read and studied". Benn was at pains to point out that in matters of such difficulty it was worth listening to everyone and that "the pressures that are brought to bear are not-as is sometimes suggested-only those brought by the environmental lobby against the innocent nuclear power lobby". Benn went on "In my political life I have never known such a wellorganised scientific, industrial, and technical lobby as the nuclear power lobby. It is not so much the Friends of the Earth as what Eisenhower might have called the nuclear industrial complex of which I am aware as a Minister."

With that view, one might have expected Benn to be more forthcoming on the question of an inquiry into the proposed building of a commercial prototype fast breeder reactor in the UK, the $£ 2$ billion CFBR1. Mr Peter Shore, Secretary of State for the Environment, has promised a fast breeder inquiry separate from the recent Windscale planning inquiry, which investigated the extension of reprocessing facilities at Windscale. Asked if the government had indeed committed itself to an inquiry on the fast breeder Benn said "We have not yet decided to set up the inquiry". And yet he added "We shall not reach a decision (on the CFBR1) until there has been an inquiry".

Mr Tom King asked for confirmation that the government would not take a decision on fast breeders until the inquiry, and suggested that the Minister had not even discussed the question of an inquiry with other Ministers. Is there progress towards an inquiry, he asked? Benn, apparently cornered, answered "I cannot undertake that there will be a debate ... when we have settled the thermal reactor question I shall be better able to answer".

Robert Walgate

analysis of the economics of nuclear systems and no awareness of the importance of storage and transport costs", said Dr Chapman.

The next public hearing, which will be held in Brussels on 25 January, will discuss some of the problems raised by the safety aspects of nuclear energy.

David Dickson 